Terbit online pada laman web jurnal: http://jurnal.iaii.or.id

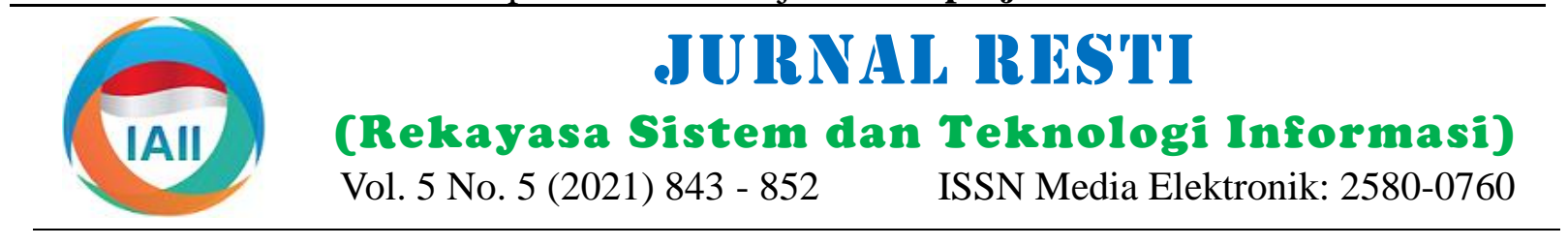

\title{
Analisis Kinerja Skema MPEG Surround Pada Pengkodean Audio 22 Kanal Menggunakan Bitrate 1000 - 2000 Kbps
}

\author{
Vitral JR ${ }^{1}$, Ahmad Ridwan $^{2}$, Habib Satria ${ }^{3}$, Ikhwana Elfitri ${ }^{4}$ \\ 1,2,3,4 Jurusan Teknik Elektro, Fakultas Teknik, Universitas Andalas \\ ${ }^{2}$ Teknik Elektronika, Politeknik Jambi \\ ${ }^{3}$ Jurusan Teknik Elektro, Fakultas Teknik, Universitas Medan Area \\ ridwan@ politeknikjambi.ac.id*
}

\begin{abstract}
MPEG surround is one of the most popular multichannel audio coding standards used today. In producing quality sound, there are several parts that are influential, but those that are directly related to sound reproduction, one of which is the method of downmixing, mixing the right channels will improve the quality of the sound produced. Because this research is closely related to data computing, the Matrix Laboratory (MATLAB) application is used. There are 2 stages carried out in the MATLAB application, namely the encoding and decoding process. In the encoding process in MATLAB, each audio channel is set according to a previously designed scheme. The results of this encoding are then decoded, so that the ODG value of each tested audio channel is obtained. In his presentation, the design and analysis of several domnmixing schemes was carried out. There are 5 schemes tested and to determine the performance of each scheme, these schemes are tested at high bitrates, from the range of $1000 \mathrm{Kbps}$ to $2000 \mathrm{Kbps}$. Based on the test, it was found that the effect of increasing the bitrate is directly proportional to the resulting audio quality. During testing Scheme-5 has a better level of stability among all downmixing schemes and the average percentage increase in Objective Difference Grade (ODG) for all audio samples is $9.6927 \%$.
\end{abstract}

Keywords: 22 Channel Audio Coding, Matlab, MPEG Surround, Downmixing, Objective Difference Grade

\begin{abstract}
Abstrak
MPEG surround merupakan salah satu standard pengkodean audio multikanal yang populer digunakan saat ini. Dalam menghasilkan suara yang berkualitas, ada beberapa bagian yang berpengaruh, namun yang berkaitan langsung dengan reproduksi suara, salah satunya adalah metode dalam melakukan downmix, percampuran kanal yang tepat akan meningkatkan kualitas dari suara yang dihasilkan. Dikarenakan penelitian ini berkaitan erat dengan komputasi data, maka digunakanlah aplikasi Matrix Laboratory (MATLAB). Ada 2 tahap yang dilakukan pada aplikasi MATLAB, yaitu proses encoding dan decoding. Pada proses encoding di MATLAB, disetting setiap kanal audio sesuai dengan skema yang telah dirancang sebelumnya. Hasil dari encoding ini kemudian di decode, sehingga didapatkan nilai ODG dari setiap kanal audio yang diujikan. Pada pemaparannya dilakukan perancangan dan analisis terhadap beberapa skema domnmixing. Terdapat 5 skema yang diujikan dan untuk mengetahui performansi dari tiap skema, skema tersebut diuji pada bitrate tinggi mulai dari range 1000 Kbps sampai dengan $2000 \mathrm{Kbps}$. Berdasarkan pengujian didapati bahwa pengaruh kenaikan bitrate berbanding lurus terhadap kualitas audio yang dihasilkan. Selama pengujian Skema-5 memiliki tingkat kestabilan yang lebih baik diantara semua skema downmixing dan rata-rata persentase kenaikan Objective Difference Grade (ODG) untuk seluruh sampel audio adalah 9,6927 $\%$.
\end{abstract}

Kata kunci: Pengkodean Audio 22 Kanal, Matlab, MPEG Surround, Downmixing, Objective Difference Grade

\section{Pendahuluan}

Perkembangan ilmu pengetahuan dan teknologi berkembang sangat pesat, termasuk di bidang media dan hiburan. Dengan perkembangan ini, ada permintaan yang meningkat untuk peralatan audio dan video yang berkualitas tinggi dan up-to-date. Pengkodean audio adalah teknik untuk merepresentasikan audio dalam bentuk digital dan didefinisikan oleh kompresi audio, membuat bitrate lebih efisien [1]. Hal ini tentunya jika audio dikirim langsung untuk digunakan dalam siaran televisi. Salah satu aplikasi pengkodean audio adalah sistem suara multi-saluran 5.1 yang digunakan oleh stasiun televisi digital Jepang, dan suara yang dihasilkan dapat memberikan sensasi dua arah kepada penonton 
rumahan. Namun, karena pendengaran yang belum sinyal residu[15]. Spatial parameter yang diekstrak ini alami, Japan Number Broadcasting Coorporation nanti akan berperan sebagai parameter buat (NHK) terus mengembangkan sistem audio multi- merekonstruksi kembali sinyal mono dari hasil proses channel 22,2 untuk aplikasi pada televisi generasi downmix jadi audio multikanal kembali [20]. Proses berikutnya, televisi definisi tinggi ultra (UHDTV) yang downmixing pada audio multikanal 22.2 bisa dilihat menghasilkan suara dalam tiga dimensi [2][3][4][5]. pada gambar 1.

Standar UHDTV diterbitkan oleh International Telecomunication Union dan dikenal sebagai Hi-Vision. Dengan teknologi ini, video yang dihasilkan menjadi jauh lebih tajam dan resolusi tinggi dengan mengesankan sistem pengkodean audio multichannel 5.1[5], 10.2[6] dan 22.2[7][8][9][10][11] jauh lebih baik dibandingkan dari sistem audio konvensional.

Banyak penelitian telah dilakukan pada pengkodean audio multichannel. Sebuah penelitian sebelumnya audio spasial atau sistem yang biasa disebut pengkodean kedua adalah Reverse Two-To-Three (R-TTT) yang audio multichannel[12][13]. Pengujian penyandian berfungsi untuk mengkonversi tiga kanal audio masukan audio multichannel 5.1 untuk salah satu codec yaitu menjadi dua kanal audio. Dan pasangan dari modul RMPEG Surround dilakukan pada berbagai rentang TTT ini adalah modul Two-To-Three (TTT)[17] yang kecepatan bit rendah, tetapi pengujian selanjutnya nantinya akan menguraikan kembali dua kanal audio ternyata mempengaruhi kualitas pemutaran audio[13]. masukan menjadi tiga kanal audio.

Hal ini dilakukan dengan menggunakan metode closed loop karena ditemukannya kekurangan pada metode open loop yaitu tidak adanya kemampuan untuk meminimalisir error pada saat kompresi audio multichannel. Studi ini menunjukkan bahwa audio terkompresi dari suara surround MPEG closed loop yang merupakan pengujian objektif dan subjektif, berkinerja lebih baik daripada open loop. Diketahui juga bahwa menggunakan codec ini pada bitrate yang tinggi dapat meningkatkan kualitas suara MPEG Surround. Oleh karena itu sangat disarankan menggunakan MPEG Surround untuk kualitas suara yang lebih baik.

Dalam studi lain[14], suara 3D yang dihasilkan oleh sistem pengkodean audio multichannel 22.2 memiliki kualitas suara yang lebih baik dan kesan realisme daripada sistem audio multichannel 5.1 dan 2.0. Ada beberapa faktor yang dapat mempengaruhi dalam menghasilkan suara berkualitas tinggi, tetapi bagian yang berhubungan langsung dengan reproduksi suara adalah kualitas suara yang dihasilkan ditingkatkan dengan pencampuran kanal yang tepat. Oleh karena itu, pada penelitian ini akan menganalisis skema pencampuran yang berbeda untuk menentukan kinerja sistem pengkodean suara 22 kanal dan mereproduksi audio yang dihasilkan dalam kisaran kecepatan bitrate $1000 \mathrm{Kbps}$ sampai $2000 \mathrm{Kbps}$ berdasarkan pada parameter Objective Difference Grade (ODG).

\section{Metode Penelitian}

Proses downmixing audio multikanal 22.2 dilakukan dengan metode sinyal audio masukan 22 kanal diproses pada block downmix yang berisikan encoding block serta dikonversi jadi satu audio mono dengan spatial parameternya yang berbentuk CLD, ICC dan suatu

DOI: https://doi.org/10.29207/resti.v5i5.3372

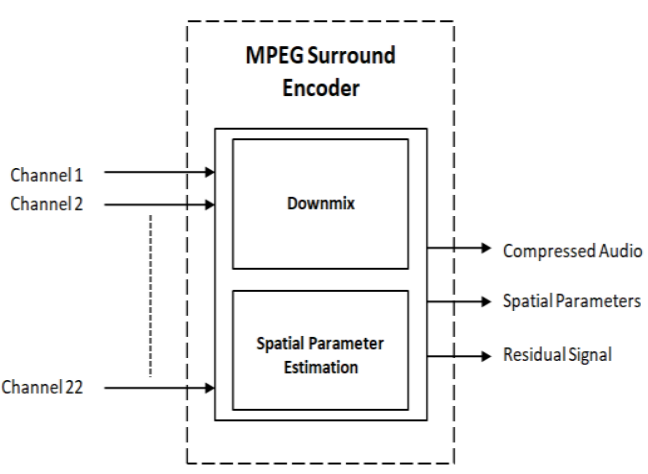

Gambar 1. Blok Diagram Downmixing Pada Audio Multikanal 22.2[18]

Blok modul R-OTT akan melakukan proses downmixing audio multikanal menjadi audio mono dan spatial parameter berupa Channel Level Difference (CLD) yang menunjukkan perbedaan level antara dua kanal audio masukan dan Inter-Channel Coherence (ICC) yang menggambarkan ukuran kemiripan kedua sinyal masukan[19][20][21]. Dari kedua audio masukan $X_{1}[n]$ dan $\mathrm{X}_{2}[\mathrm{n}]$, kemudian di downmix menjadi satu kanal keluaran $Y[n][22][23]$.

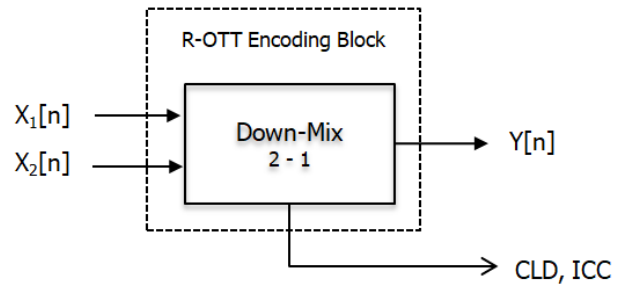

Gambar 2. Struktur encoding blok R-OTT[21]

Creative Commons Attribution 4.0 International License (CC BY 4.0) 
Proses downmixing audio multikanal 22.2 dengan Sedangkan perancangan modul R-OTT downmixing menggunakan codec MPEG Surround akan dilakukan audio 22 kanal skema 2.

dengan merancang 5 skema downmixing dengan menggunakan modul Reverse One-To-Two (R-OTT).

\subsection{Perancangan Skema 1}
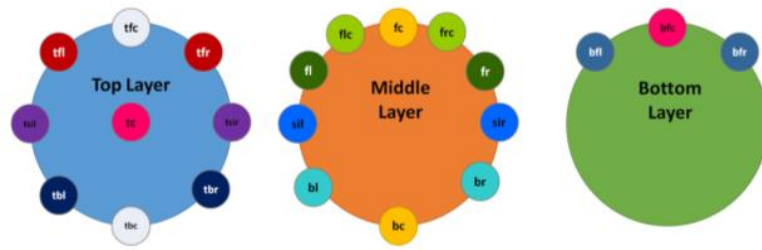

Gambar 3. Perancangan Lapisan Audio Skema 1 Downmixing

Pada skema pertama, input audio dirancang dengan sepasang saluran pada layer yang sama. Lapisan tengah memiliki sepasang 5 saluran audio yaitu, kanal Fc dan Bc, kanal Flc dan Frc, kanal Fl, Fr dan kanal Sil. Satu memiliki kanal Sir, kemudian kanal Bl dengan kanal Br.

Untuk lapisan atas terdapat 4 kanal yang dipasangkan dalam satu layer yaitu kanal Tfc dipasangkan dengan kanal Tbc, kanal Tfl dengan kanal Tfr, kanal Tsil dengan kanal Tsir, kanal Tbl dengan kanal Tbr, namun dikarenakan pada layer ini hanya terdapat sembilan kanal, maka kanal Tc dipasangkan dengan kanal Bfc pada layer bawah. Kemudian satu pasang lainnya yaitu kanal Bfl dengan kanal Bfr. Proses downmixing yang melalui beberapa modul R-OTT, setiap masing-masing modul R-OTT akan mengekstrak 3 sinyal yaitu audio hasil downmixing, spatial parameter berupa CLD dan ICC serta sebuah sinyal residu.

\subsection{Perancangan Skema 2}

Selanjutnya pada skema kedua, perancangan audio masukan disusun bersumber pada pada susunan audio 22 kanal, dimana posisi kanal audio dalam satu layer yang sama serta bersebelahan secara garis horizontal. Pada susunan tengah ada 5 pasang kanal audio yaitu kanal Fc dengan kanal Bc, kanal Fl dengan kanal Bl, kanal Fr dengan kanal Br, kanal Flc dengan kanal Sil, serta terakhir kanal Frc dengan kanal Sir. Untuk lapisan atas ada 4 kanal yang dipasangkan, yaitu kanal Tfc dengan kanal Tbc, ialah kanal Tfc dengan kanal Tbc, kanal Tfl dengan kanal Tbl, kanal Tfr dengan kanal Tbr, serta kanal Tsil dengan kanal Tsir. Untuk kanal Tc pada layer kedua ini dipasangkan dengan kanal Bfc pada layer dasar, serta yang terakhir kanal Bfl dipasangkan dengan kanal Bfr. Gambar 4 menampilkan perancangan susunan kanal pada skema 2.
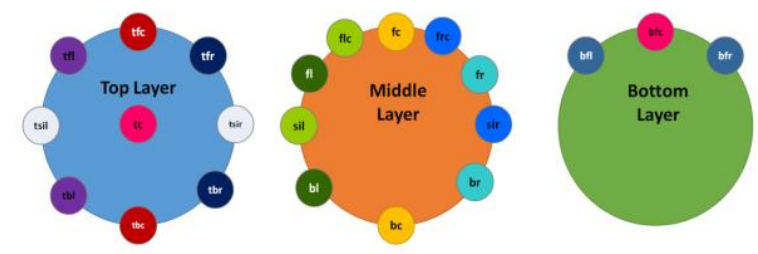

Gambar 4. Perancangan Lapisan Audio Skema 2 Downmixing

\subsection{Perancangan Skema 3}
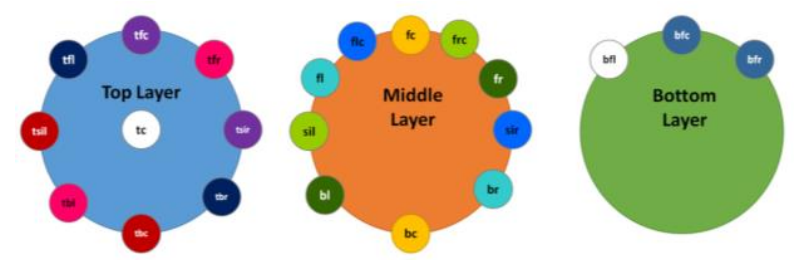

Gambar 5. Perancangan Lapisan Audio Skema 3 Downmixing

Skema ketiga ini semua kanal pada layer tengah akan dipasangkan dengan kanal dalam satu layer yang sama, yaitu kanal Fc dengan kanal Bc, kanal Flc dengan kanal Sir, kanal Fl dengan kanal Br, kanal Frc dengan kanal Sil, dan kanal Fr dengan kanal Bl. Pada layer atas, satu kanal dipasangkan antar layer seperti kanal Tc dipasangkan dengan kanal Bfl pada layer bawah, dan untuk kanal lainnya masih tetap dalam satu layer, yaitu kanal Tfc dengan kanal Tsir, kanal tfl dengan kanal Tbr, kanal Tsil dengan kanal Tbc, kanal Tfr dengan kanal Tbl. Dan untuk layer bawah, kanal Bfc dipasangkan dengan kanal Bfr.

\subsection{Perancangan Skema 4}

Pada skema keempat ini perancangan audio dilakukan dengan mendownmix kanal antar layer yang berbeda. Kanal Flc pada layer tengah dipasangkan dengan kanal Bfl pada layer bawah, kanal Fc layer tengah dipasangkan dengan kanal Tfc layer atas, kanal Frc dengan kanal Bfr, kanal Fr dengan kanal Tfr, kanal Sir dengan kanal Tsir, kanal br dengan kanal Tbr, kanal Bc dengan kanal Tbc, kanal Bl dengan kanal Tbl, kanal Sil dengan kanal Tsil, kanal Fl dengan kanal Tfl, dan kanal Tc dengan kanal Bfc. Susunan perancangan skema 4 dapat dilihat pada gambar 6.
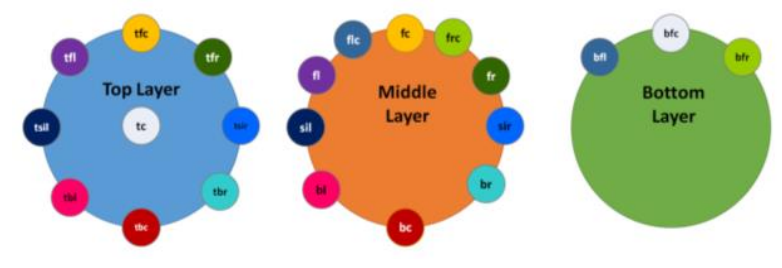

Gambar 6. Perancangan Lapisan Suara Skema 4 Downmixing

Adapun pada skema kelima pada gambar7 dirancang dengan rujukan pada skema awal, namun diberikan beberapa improvisasi dengan pergantian urutan kanal pada saat downmixing, kanal yang berganti urutan pada skema kelima ini dapat dilihat pada tabel 1 .

DOI: https://doi.org/10.29207/resti.v5i5.3372

Creative Commons Attribution 4.0 International License (CC BY 4.0) 


\subsection{Perancangan Skema 5}
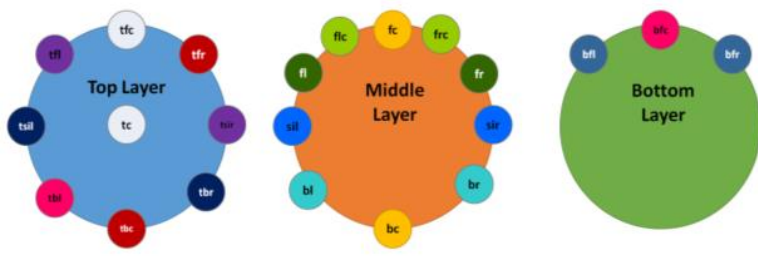

Gambar 7. Perancangan Lapisan Suara Skema 5 Downmixing

Tabel 1 menjelaskan perbandingan urutan kanal, sebagai contoh pada skema 1 kanal Sir serta kanal Sil terletak pada urutan 7 serta 8 , sebaliknya pada skema 5 jadi urutan 3 serta 4, kanal $\mathrm{Br}$ serta kanal $\mathrm{Bl}$ pada skema 1 pada urutan 9 serta 10 sebaliknya pada skema 5 pada urutan 5 serta 6.

Tabel 1. Perbedaan Urutan Kanal Suara Skema 1 dan Skema 5

\begin{tabular}{ccc}
\hline Kanal Suara & Skema 1 & Skema 5 \\
\hline 1 & fc & Fc \\
2 & bc & Bc \\
3 & frc & Sir \\
4 & flc & Sil \\
5 & fr & Br \\
6 & fl & Bl \\
7 & sir & Fr \\
8 & sil & Fl \\
9 & br & Frc \\
10 & bl & Flc \\
11 & tfc & Tc \\
12 & tbc & Tfc \\
13 & tfr & Tsil \\
14 & tfl & Tbr \\
15 & tsir & Tfl \\
16 & tsil & Tsir \\
17 & tbr & Tbc \\
18 & tbl & Tfr \\
19 & bfr & Bfr \\
20 & bfl & Bfl \\
21 & tc & Tbl \\
22 & bfc & Bfc \\
\hline
\end{tabular}

\section{Hasil dan Pembahasan}

Dikarenakan penelitian ini berkaitan erat dengan komputasi data, maka digunakanlah aplikasi Matrix Laboratory (MATLAB). Ada 2 tahap yang dilakukan pada aplikasi MATLAB, yaitu proses encoding dan decoding. Pada proses encoding di MATLAB, diset setiap kanal audio sesuai dengan skema yang telah dirancang sebelumnya. Hasil dari encoding ini kemudian didecode, sehingga didapatkan nilai ODG dari setiap kanal audio yang diujikan. Pada bagian pengujian menggunakan kelima jenis skema kanal audio masukan. Sampel audio yang digunakan pada penelitian ini Pengujian tersebut dengan menggunakan codec MPEG menggunakan 3 jenis audio yang berbeda beda dengan Surround 22 channel pada bitrate $1000 \mathrm{Kbps}$ sampai format ".wav" yang terdiri dari 22 kanal (sistem audio 2000 Kbps menggunakan program MATLAB. Hasil multikanal 22.2). Tabel 3 menampilkan sampel audio multikanal yang akan digunakan untuk pengujian.

Tabel 2. Skala Nilai ODG dan SDG

\begin{tabular}{|c|c|c|c|}
\hline ODG & SDG & Kualitas & Deskripsi \\
\hline 0.0 & 0.0 & Sangat Baik & $\begin{array}{c}\text { Imperceptible (tak terdengar } \\
\text { perbedaan) }\end{array}$ \\
\hline-1.0 & -1.0 & Baik & $\begin{array}{c}\text { Perceptible, but not annoying } \\
\text { (terdengar beda, tapi tidak } \\
\text { mengganggu) }\end{array}$ \\
\hline-2.0 & -2.0 & Cukup & $\begin{array}{l}\text { Slightly annoying (sedikit } \\
\text { mengganggu) }\end{array}$ \\
\hline-3.0 & -3.0 & Buruk & Annoying (mengganggu) \\
\hline-4.0 & -4.0 & Sangat Buruk & $\begin{array}{l}\text { Very annoying (sangat } \\
\text { mengganggu) }\end{array}$ \\
\hline
\end{tabular}

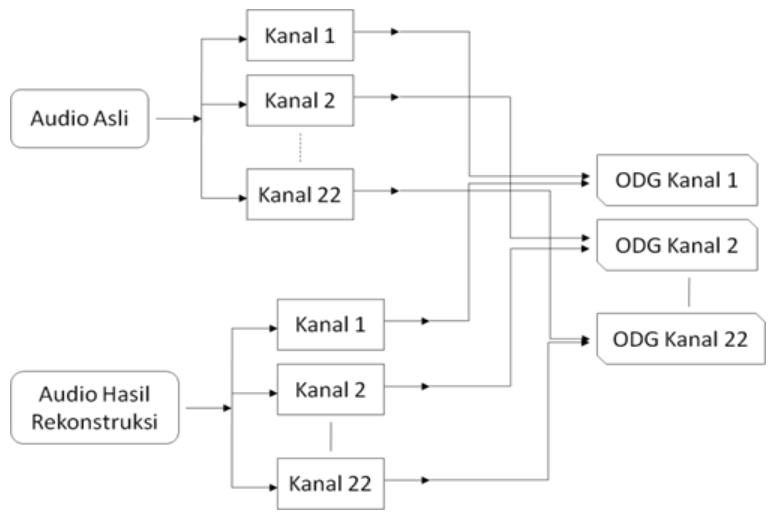

Gambar 8. Blok Diagram Pengukuran Nilai ODG pada pengkodean audio 22,2

Pada gambar 8 merupakan konsep pengukuran nilai ODG pada penelitian ini, dimana audio hasil rekonstruksi yang direproduksi pada decoder MPEG Surround dibandingkan dengan audio asli sebelum diproses pada encoder MPEG Surround. Parameter ODG ini juga dipakai untuk mengetahui seberapa jauh turunnya kualitas audio hasil kompresi dengan audio aslinya saat proses kompresi.

DOI: https://doi.org/10.29207/resti.v5i5.3372

Creative Commons Attribution 4.0 International License (CC BY 4.0) 
Vitral JR, Ahmad Ridwan, Habib Satria, Ikhwana Elfitri

Jurnal RESTI (Rekayasa Sistem dan Teknologi Informasi) Vol. 5 No. 5 (2021) 843 - 852

Tabel 3. Sampel Multichannel Audio

\begin{tabular}{cc}
\hline No & Sampel Audio \\
\hline 1 & bulg22ch.wav \\
2 & folk22ch.wav \\
3 & applause22ch.wav \\
\hline
\end{tabular}

\subsection{Perbandingan Audio Pada Bitratre $1500 \mathrm{Kbps}$}

Penelitian ini dilakukan untuk menganalisa performansi dari skema downmixing pada Audio Codec MPEG Surround. Objective Difference Grade merupakan skala yang digunakan untuk menguji kualitas audio hasil kompresi menggunakan closed loop R-OTT module, yang diterapkan pada MPEG Surround dan kemudian dibandingkan dengan seluruh skema downmixing. Audio yang digunakan pada penelitian ini adalah Applause22ch, Bulg22ch, dan Folk22ch. Adapun hasil pengukuran ODG yang menyatakan kualitas dari closedloop R-OTT per masing masing audio dapat dilihat pada tabel 4.1 Untuk data ODG dari masing-masing skema yang lebih detail dengan 3 sampel audio uji yang berbeda penulis tampilkan pada lampiran A, B dan C. Pada lampiran A ditampilkan data dari setiap kanal per skema downmixing, dengan sampel audio Applause22ch. Untuk lampiran B pengujian dengan sampel audio Bulg22ch, dan pada lampiran $\mathrm{C}$ pengujian dengan sampel audio Folk22ch. Tabel 4.1 Hasil pengukuran ODG closed loop R-OTT masing masing audio pada bitrate $1500 \mathrm{Kbps}$.

Tabel 4. Hasil Pengukuran ODG Closed Loop R-OTT MasingMasing Audio pada Bitrate $1500 \mathrm{Kbps}$

\begin{tabular}{ccccc}
\hline No & $\begin{array}{c}\text { Sampel } \\
\text { Audio }\end{array}$ & Bulg22ch & Folk22ch & $\begin{array}{c}\text { Applause22 } \\
\text { ch }\end{array}$ \\
\hline 1 & Skema 1 & $-0,52411$ & $-0,52189$ & $-0,29478$ \\
2 & Skema 2 & $-0,54468$ & $-0,51096$ & $-0,28557$ \\
3 & Skema 3 & $-0,55132$ & $-0,50294$ & $-0,28120$ \\
4 & Skema 4 & $-0,51130$ & $-0,60997$ & $-0,31704$ \\
5 & Skema 5 & $-0,54732$ & $-0,50228$ & $-0,28114$ \\
\hline
\end{tabular}

Berdasarkan tabel 4 bahwa pada sampel audio Applause22ch hasil kompresi audio yang dihasilkan jauh lebih baik dibandingkan dengan sampel lainnya, hal ini dapat dilihat dengan meningkatnya nilai ODG pada semua skema yang menggunakan sampel Bulg22ch. Pada gambar 14 menunjukkan semua skema downmixing menghasilkan pola yang sama dalam mereproduksi audio, namun pada Bulg22ch skema 4 menunjukkan hasil yang lebih baik untuk digunakan dibandingkan 4 skema lainnya, dengan nilai ODG sebesar $-0,5113 \mathrm{~dB}$. Namun sebaliknya pada tabel 5 yang menunjukkan hasil rata-rata gabungan pengujian memperlihatkan bahwa skema 4 memiliki kinerja yang paling tidak baik diantara semua skema, dengan selisih sebesar $-0,03 \mathrm{~dB}$.

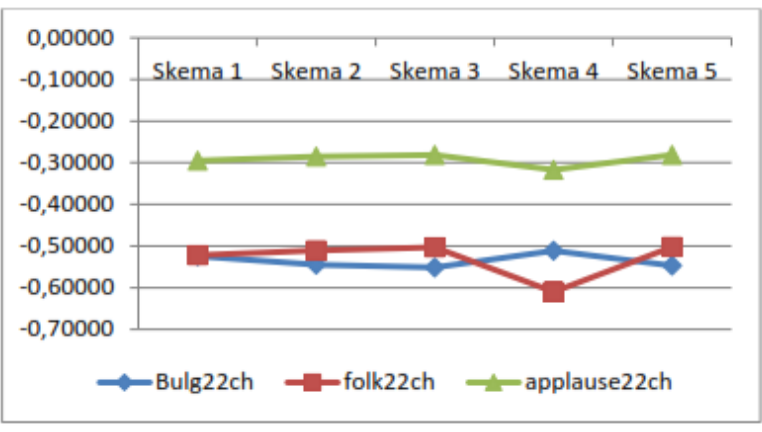

Gambar 9. Grafik Pengukuran ODG Pada Bitrate 1500 Kbps

Tabel 5. Hasil Pengukuran rata-rata ODG Closed Loop R-OTT Pada Bitrate $1500 \mathrm{Kbps}$

\begin{tabular}{ccc}
\hline No & Sampel Audio & Rata-rata Hasil Pengujian \\
\hline 1 & Skema 1 & $-0,44693$ \\
2 & Skema 2 & $-0,44707$ \\
3 & Skema 3 & $-0,44515$ \\
4 & Skema 4 & $-0,47944$ \\
5 & Skema 5 & $-0,44358$ \\
\hline
\end{tabular}

\subsection{Perbandingan Audio Pada Bitratre $1500 \mathrm{Kbps}$}

Pengukuran Objective Difference Grade (ODG) digunakan untuk mengevaluasi kualitas dari masingmasing sinyal audio. Bagian ini analisis dilakukan terhadap masing-masing skema dari setiap sampel audio yang diujikan, kemudian hasil ODG tersebut dibandingkan dari bitrate $1000 \mathrm{Kbps}$ sampai dengan $2000 \mathrm{Kbps}$, range ini dipilih berdasarkan penelitian yang telah dilakukan sebelumnya dimana codec MPEG Surround ini akan menghasilkan kualitas yang lebih baik pada bitrate tinggi.

Nilai ODG semua audio meningkat seiring dengan kenaikan bitrate. Sampel audio Applause22ch menunjukkan performa terjadinya kenaikan nilai ODG pada bitrate $1000 \mathrm{Kbps}$ ke $1100 \mathrm{Kbps}$ yaitu dari $-0,6325$ dB menjadi -0,5275 dB dengan kenaikan ODG sebesar $0,1051 \mathrm{~dB}$, lalu pada bitrate $1200 \mathrm{kbps}$ naik lagi sebesar $-0,0723 \mathrm{~dB}$ menjadi $-0,4552 \mathrm{~dB}$, kemudian secara berturut-turut kenaikan ODG adalah 0,06814, -0,06613, $-0,0261,-0,0166,-0,0259,-0,0170,-0,0230,-0,0130$.

Performa nilai ODG pada skema 1 terhadap sampel audio Bulg22ch menunjukkan bahwa terjadi kenaikan nilai ODG yang sangat signifikan pada bitrate 1100 Kbps ke 1200 Kbps yaitu sebesar -0,1850 dB dari yg semula $-1,0461 \mathrm{~dB}$ menjadi $-0,8611 \mathrm{~dB}$, kemudian secara berturut-turut terjadi kenaikan ODG yaitu $0,0947,-0,1354,-0,0761,0,0308,-0,0807,-0,0545$, $0,0338,-0,0394,-0,0200$.

Selanjutnya performa nilai ODG dari skema 1 pada sampel audio Folk22ch hampir sama dengan pengujian pada sampel Bulg22ch, pada sampel ini juga terjadi kenaikan yang cukup signifikan pada bitrate $1100 \mathrm{Kbps}$ ke $1200 \mathrm{Kbps}$ yaitu sebesar -0,2271 dB, selain itu juga terdapat pada bitrate $1400 \mathrm{Kbps}$ ke $1500 \mathrm{Kbps}$ yaitu

DOI: https://doi.org/10.29207/resti.v5i5.3372

Creative Commons Attribution 4.0 International License (CC BY 4.0) 
sebesar $-0,0954 \mathrm{~dB}$. Dari data tersebut dapat dilihat terus berlanjut yaitu $-0,0726 \mathrm{~dB}$ menjadi $-0,4400 \mathrm{~dB}$, bahwa semakin tinggi bitrate yang diujikan maka kemudian secara berturut-turut kenaikan ODG yaitu kenaikan nilai ODG tidak begitu signifikan dirasakan, 0,0670, -0,0597, -0,0277, -0,0168, -0,0240, -0,0195, dan juga berdasarkan nilai ambang batas dan bawah $0,0233,-0,0133$.

maka dapat dikatakan performansi yang dihasilkan semakin fokus pada titik median.

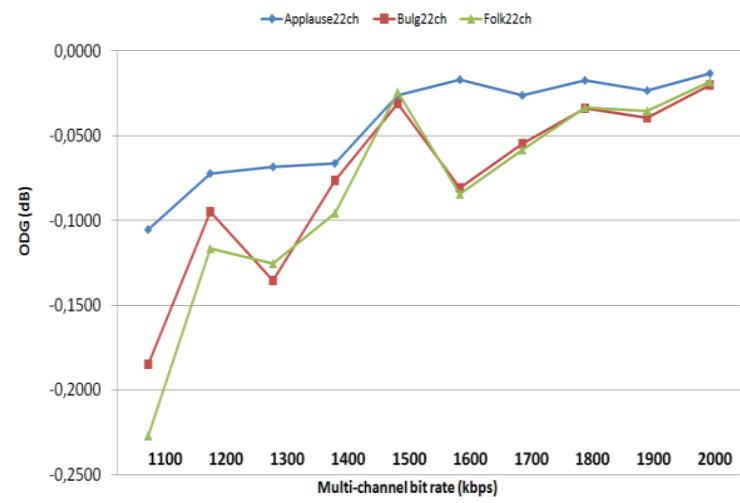

Gambar 10. Grafik Perbandingan Performansi Skema 1 per Sampe Audio

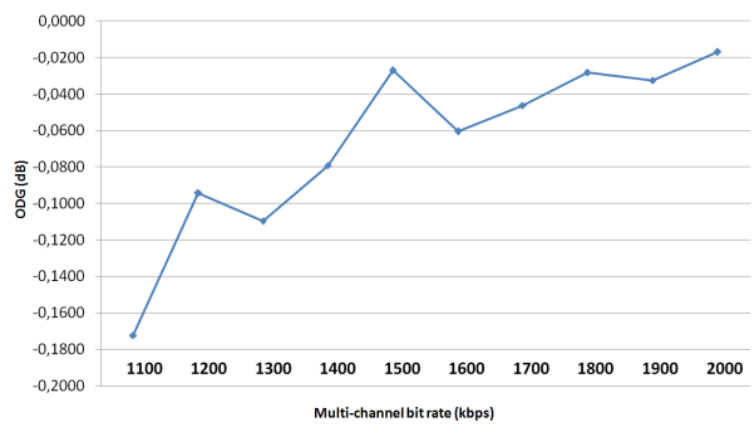

Gambar 11. Grafik Performansi Skema 1 Gabungan Seluruh Sampe Audio

Gambar 10 dan 11 menunjukkan tingkat perfomansi downmixing pada skema 1. Berdasarkan gambar 18 dapat dianalisa bahwa secara keseluruhan sampel pengujian audio Applause22ch menghasilkan kualitas yang lebih baik dibandingkan dengan sampel audio Bulg22ch, dan Folk22ch. Sedangkan pada gambar 19 merupakan hasil gabungan rata-rata pengujian ketiga sampel audio pada skema 1. Pada gambar tersebut juga menunjukkan kenaikan nilai ODG, dimana terdapat dua titik yang mengalami performansi yang signifikan yaitu pada bitrate 1100 Kbps ke 1200 Kbps mengalami kenaikan performasi sebesar 45,17\% (-0,0779 dB) dan pada bitrate 1400 ke $1500 \mathrm{Kbps}$ sebesar 65,91\% atau $0,0522 \mathrm{~dB}$.

Peningkatan nilai ODG untuk semua audio jika angka bitrate semakin tinggi. Skema 2 pada sampel audio Applause22ch menunjukkan terjadinya performa kenaikan nilai ODG pada bitrate $1000 \mathrm{Kbps}$ ke 1100 Kbps yaitu mulai dari nilai -0,6476 dB menjadi -0,5126 Applause22ch. Dimana terjadinya kenaikan nilai ODG dB. Terjadi kenaikan nilai ODG sebesar $-0,1351 \mathrm{~dB}$, pada bitrate $1000 \mathrm{Kbps}$ ke $1100 \mathrm{Kbps}$ yaitu dari $-0,6289$ selanjutnya pada bitrate $1200 \mathrm{Kbps}$ kenaikan nilai ODG dB menjadi -0,5176 dB dengan kenaikan ODG sebesar -

DOI: https://doi.org/10.29207/resti.v5i5.3372
Performa nilai ODG pada skema 2 terhadap sampel audio Bulg22ch, dimana data menunjukkan bahwa kenaikan nilai ODG yang sangat signifikan pada bitrate $1100 \mathrm{Kbps}$ ke $1200 \mathrm{Kbps}$ yaitu sebesar $-0,1802 \mathrm{~dB}$ dari awalnya nilai ODG $-1,1074 \mathrm{~dB}$ menjadi $-0,9272 \mathrm{~dB}$.

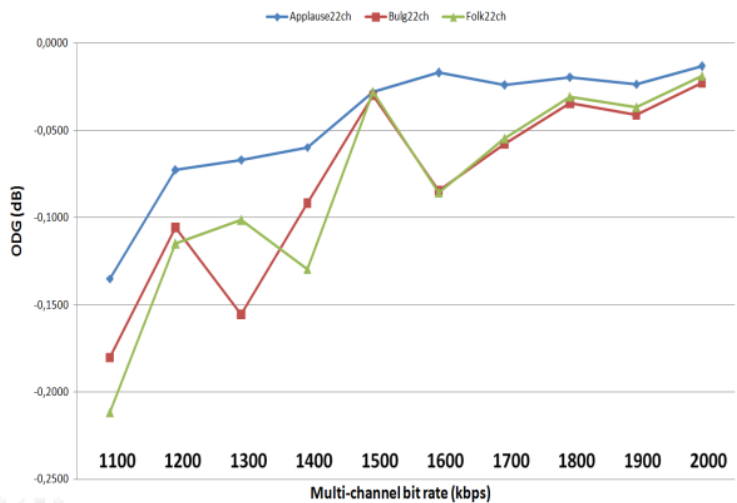

Gambar 12. Grafik Perbandingan Performansi Skema 2 per Sampel Audio

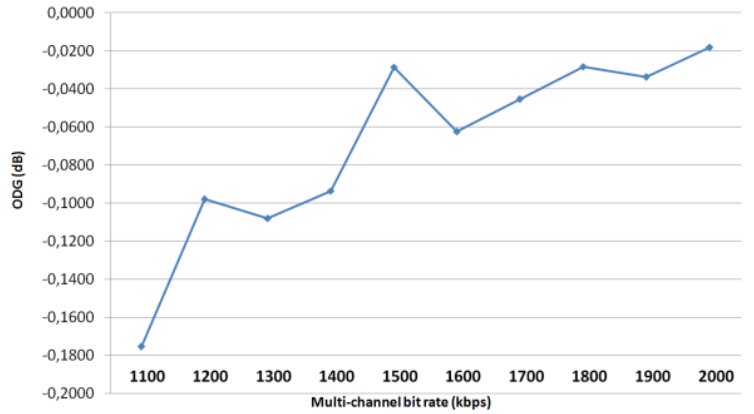

Gambar 13. Grafik Performansi Skema 2 Gabungan Seluruh Sampel Audio

Pada gambar 10 dapat dianalisa bahwa secara keseluruhan sampel pengujian audio Applause22ch menghasilkan kualitas audio yang lebih baik dibandingkan dengan sampel audio Bulg22ch, dan Folk22ch. Sementara gambar 13 merupakan hasil gabungan dan rata-rata pengujian ketiga sampel audio pada skema 2, pada gambar tersebut menunjukkan besaran kenaikan dari nilai ODG, terdapat dua titik yang pada bitrate $1100 \mathrm{Kbps}$ sampai bitrate $1200 \mathrm{Kbps}$ terjadi kenaikan performansi sebesar 44,31\% (-0,0778 dB) sedangkan pada bitrate 1400 ke 1500 Kbps kenaikan sebesar $69,60 \%(0,0652 \mathrm{~dB})$

Kenaikan nilai ODG skema 3 dengan sampel audio mengalami kenaikan performansi yang signifikan yaitu 
0,1112 dB. Kemudian pada bitrate $1200 \mathrm{Kbps}$ juga dengan sampel audio Bulg22ch, dan Folk22ch. terjadi kenaikan nilai ODG sebesar -0,0756 dB menjadi Kemudian pada gambar 15 merupakan hasil gabungan $-0,4420 \mathrm{~dB}$. dan rata-rata pengujian ketiga sampel audio pada skema 3. Gambar tersebut menunjukkan besaran kenaikan nilai Performa nilai ODG pada skema 3 terhadap sampel audio Bulg22ch, dimana terjadi kenaikan nilai ODG yang sangat signifikan pada bitrate $1100 \mathrm{Kbps}$ ke 1200 Kbps yaitu sebesar $-0,1758 \mathrm{~dB}$ dari semula $-1,1149 \mathrm{~dB}$ menjadi -0,9391 dB, kemudian kenaikan nilai ODG terjadi secara berturut-turut yaitu -0,0994, -0,1611, $0,0965,-0,0308,-0,0839,-0,0587,-0,0351,-0,0395$, - Analisa beberapa hal mengenai pengujian skema 4, yaitu 0,0221. Performa nilai ODG dari skema 3 dengan pada sampel audio Applause22ch menunjukkan sampel Folk22ch, dimana hampir sama dengan performa kenaikan nilai ODG pada bitrate $1000 \mathrm{Kbps}$ pengujian dengan sampel Bulg22ch. Pada sampel ke $1100 \mathrm{Kbps}$ yaitu dari nilai -0,6235 dB menjadi Folk22ch dengan bitrate 1100 Kbps ke 1200 Kbps 0,5283 dB dengan kenaikan ODG sebesar $-0,1051 \mathrm{~dB}$, terjadi kenaikan nilai ODG yang signifikan yaitu sebesar lalu pada bitrate $1200 \mathrm{kbps}$ naik sebesar $-0,0952 \mathrm{~dB}$ $-0,2063 \mathrm{~dB}$, selain itu pada bitrate $1400 \mathrm{Kbps}$ sampai menjadi -0,0655 dB.

1500 Kbps kenaikan sebesar -0,1253 dB. Dari data tersebut dapat dilihat bahwa semakin tinggi bitrate yang diujikan maka kenaikan nilai ODG tidak begitu signifikan dirasakan. Kemudian berdasarkan nilai ambang batas dan bawah maka dapat dikatakan bahwa performansi yang dihasilkan tidak melebar dan semakin fokus pada titik median.

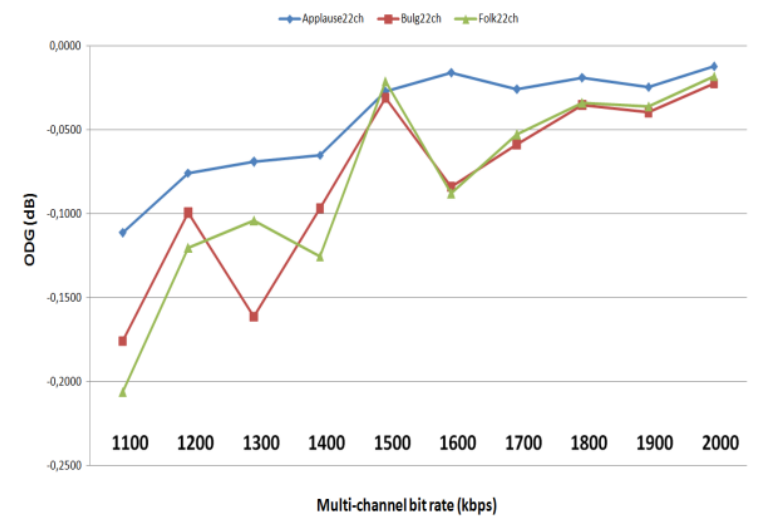

Gambar 14. Grafik Perbandingan Performansi Skema 3 Per Sampel Audio

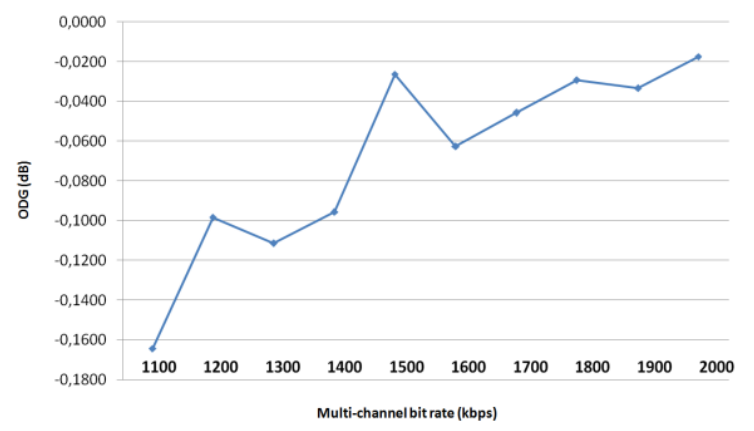

Gambar 15. Grafik Performansi Skema 3 Gabungan Seluruh Sampel Audio

Performa nilai ODG pada pengujian skema 4 dengan menggunakan sampel audio Bulg22ch, data menunjukkan bahwa terjadi kenaikan nilai ODG yang sangat signifikan pada bitrate $1100 \mathrm{Kbps}$ ke $1200 \mathrm{Kbps}$ yaitu sebesar $-0,1857 \mathrm{~dB}$ dari yang semula $-1,0444 \mathrm{~dB}$ menjadi $-0,8588 \mathrm{~dB}$, kemudian kenaikan nilai ODG terus terjadi mencapai $-0,0202 \mathrm{~dB}$.

Selanjutnya performa nilai ODG dari skema 4 dengan sampel Folk22ch, hasilnya hampir sama dengan pengujian dengan sampel Bulg22ch. Dimana pada sampel Folk22ch terjadi kenaikan yang signifikan pada bitrate $1100 \mathrm{Kbps}$ ke $1200 \mathrm{Kbps}$ yaitu sebesar -0,2234 $\mathrm{dB}$, kemudian kenaikan juga terjadi pada bitrate 1400 Kbps ke 1500 Kbps yaitu sebesar -0,1258 dB. Dari data tersebut dilihat bahwa semakin tinggi bitrate yang diujikan maka kenaikan nilai ODG tidak begitu signifikan dirasakan.

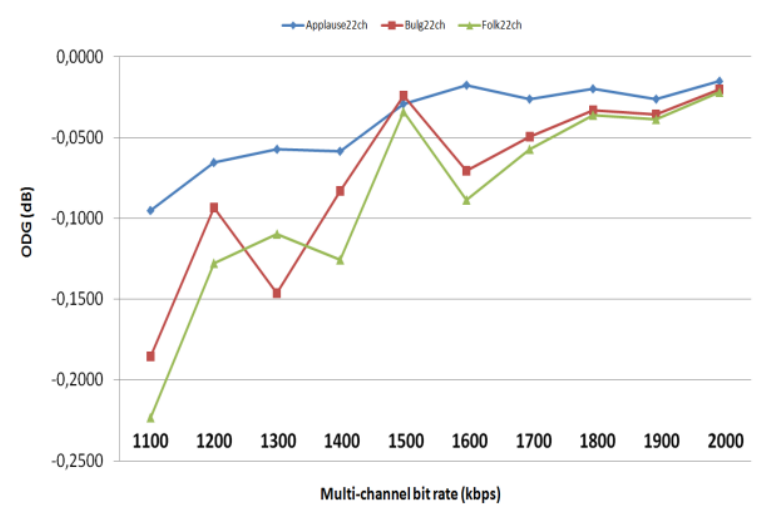

Gambar 16. Grafik Perbandingan Performansi Skema 4 Per Sampel Audio

Gambar 16 dan 17 menunjukkan perbandingan tingkat perfomansi downmixing pada skema 4. Pada gambar 16 dapat dianalisa bahwa secara keseluruhan sampel

Pada gambar 14 dapat dianalisa bahwa secara pengujian audio Applause22ch menghasilkan kualitas keseluruhan sampel pengujian audio Applause22ch yang lebih baik dibandingkan dengan sampel audio menghasilkan kualitas yang lebih baik dibandingkan Bulg22ch, dan Folk22ch. Kemudian pada gambar 17

DOI: https://doi.org/10.29207/resti.v5i5.3372

Creative Commons Attribution 4.0 International License (CC BY 4.0) 
merupakan hasil gabungan serta rata-rata pengujian Applause22ch menghasilkan kualitas yang lebih baik ketiga sampel audio pada skema 4. Gambar tersebut juga dibandingkan dengan sampel audio Bulg22ch, dan menunjukkan besaran kenaikan nilai ODG, dimana Folk22ch. Kemudian pada gambar 38 merupakan hasil terdapat dua titik yang mengalami performansi yang gabungan dan rata-rata pengujian ketiga sampel audio signifikan yaitu pada bitrate 1100 ke $1200 \mathrm{Kbps}$ terjadi pada skema 5, dimana menunjukkan besaran kenaikan performansi sebesar 43,09\% (-0,0724 dB) kemudian dari nilai ODG, terdapat dua titik yang mengalami pada bitrate 1400 ke 1500 Kbps kenaikan sebesar performansi yang signifikan yaitu pada bitrate 1100 $67,28 \%(-0,0601 \mathrm{~dB})$.

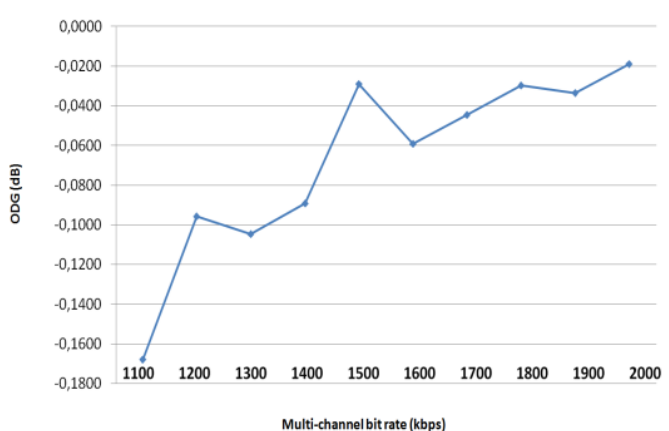

Gambar 17. Grafik Performansi Skema 4 Gabungan Seluruh Sampel Audio

Performa terjadinya kenaikan nilai ODG pada bitrate 1000 Kbps ke 1100 Kbps. Dimana kenaikan nilai ODG dari -0,6266 dB menjadi -0,5215 dB, kemudian pada bitrate 1200 Kbps kenaikan ODG sebesar -0,0751 dB menjadi -0,4464 dB, kenaikan nilai ODG terus berlanjut seiring dengan naiknya bitrare yaitu $0,0738,-0,0651$, $0,0263,-0,0169,-0,0252,-0,0187,-0,0237,-0,0132$.

Performa nilai ODG pada skema 5 dengan sampel audio Bulg22ch, data menunjukkan bahwa terjadi kenaikan nilai ODG yang sangat signifikan pada bitrate 1100 Kbps ke 1200 Kbps yaitu sebesar $-0,1837$ dB dari yg semula $-1,1014 \mathrm{~dB}$ menjadi $-0,9177 \mathrm{~dB}$, kemudian kenaikan terus berlanjut secara berturut-turut yaitu $0,0969,-0,1534,-0,0881,-0,0319,-0,0826,-0,0592$, $0,0348,-0,0417,-0,0236$.

Selanjutnya performa nilai ODG skema 5 dengan sampel Folk22ch hampir sama dengan pengujian dengan sampel Bulg22ch, pada sampel ini juga terjadi kenaikan yang signifikan pada bitrate $1100 \mathrm{Kbps}$ ke $1200 \mathrm{Kbps}$ yaitu sebesar -0,2075 dB dan juga kenaikan terjadi pada bitrate $1400 \mathrm{Kbps}$ ke $1500 \mathrm{Kbps}$ yaitu sebesar -0,1277 dB. Dari data dapat dilihat bahwa

semakin tinggi bitrate yang diujikan maka kenaikan nilai ODG tidak begitu signifikan dirasakan, dan juga berdasarkan nilai ambang batas dan bawah maka dapat dikatakan performansi yang dihasilkan tidak melebar dan semakin fokus pada titik median.

Pada gambar 18 dapat dianalisa bahwa secara keseluruhan dengan sampel pengujian audio Kbps ke $1200 \mathrm{Kbps}$ terjadi performansi sebesar 41,93\% $(-0,0694 \mathrm{~dB})$ dan pada bitrate $1400 \mathrm{ke} 1500 \mathrm{kbps}$ sebesar $70,87 \%(-0,0664 \mathrm{~dB})$.

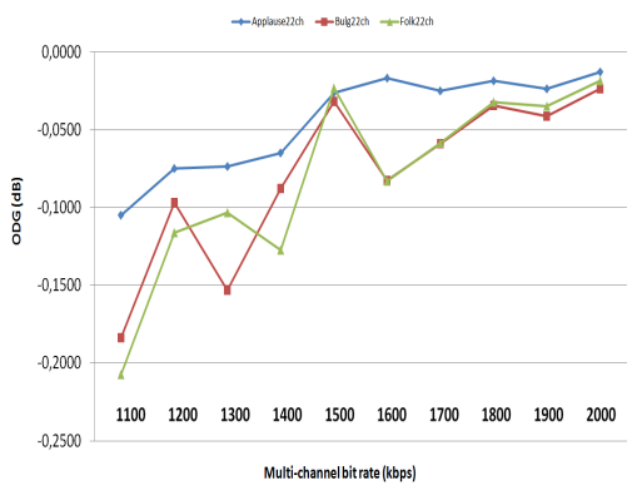

Gambar 18. Grafik Perbandingan Performansi Skema 5 Per Sampel Audio

Dari keseluruhan sampel audio pengujian, kemudian dihitung rata-rata keseluruhan per skema dalam rentang bitrate $1000 \mathrm{Kbps}$ sampai dengan $2000 \mathrm{Kbps}$, sehingga mendapatkan hasil pengujian yang secara detail dapat tampilkan. Untuk mengetahui perbandingan tiap skema yang telah dirancang, maka dilihat pada tabel 6 yang telah dikonversi dengan skala kualitas audio dalam rentang 1 sampai 5 seperti pada tabel 5 .

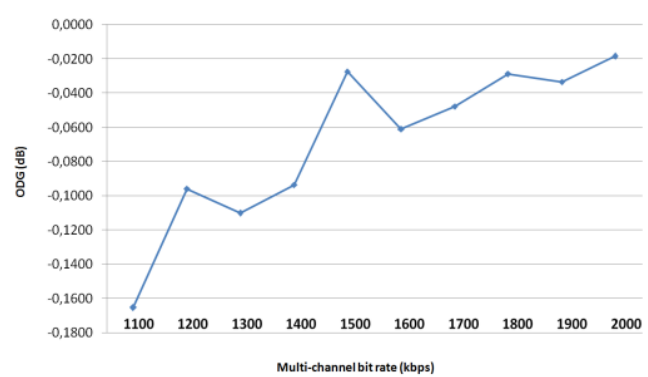

Gambar 19. Grafik Performansi Skema 5 Gabungan Seluruh Sampel Audio

Tabel 5. Skala Konversi Kualitas Pengujian Skema

\begin{tabular}{cc}
\hline Skala & Keterangan \\
\hline 5 & Sangat Bagus \\
4 & Bagus \\
3 & Cukup \\
2 & Kurang \\
1 & Tidak Bagus \\
\hline
\end{tabular}

DOI: https://doi.org/10.29207/resti.v5i5.3372

Creative Commons Attribution 4.0 International License (CC BY 4.0) 
Vitral JR, Ahmad Ridwan, Habib Satria, Ikhwana Elfitri Jurnal RESTI (Rekayasa Sistem dan Teknologi Informasi) Vol. 5 No. 5 (2021) 843 - 852

Tabel 6. Hasil Konversi Pengujian Kualitas Skema Downmixing

\begin{tabular}{cccccccccccc}
\hline Perc/Bitrate & 1000 & 1100 & 1200 & 1300 & 1400 & 1500 & 1600 & 1700 & 1800 & 1900 & 2000 \\
\hline Skema-1 & 5 & 5 & 5 & 5 & 3 & 3 & 2 & 2 & 2 & 2 & 2 \\
Skema-2 & 2 & 3 & 3 & 2 & 2 & 2 & 3 & 3 & 3 & 3 & 3 \\
Skema-3 & 3 & 2 & 2 & 3 & 4 & 4 & 4 & 4 & 4 & 4 & 4 \\
Skema-4 & 1 & 1 & 1 & 1 & 1 & 1 & 1 & 1 & 1 & 1 & 1 \\
Skema-5 & 4 & 4 & 4 & 4 & 5 & 5 & 5 & 5 & 5 & 5 & 5 \\
\hline
\end{tabular}

\section{Kesimpulan}

Berdasarkan penelitian yang telah dilakukan, maka dapat diperoleh kesimpulan bahwa pengaruh kenaikan bitrate berbanding lurus terhadap kualitas audio yang dihasilkan. Kemudian pada pengujian bitrate $1500 \mathrm{Kbps}$ terdapat kondisi titik jenuh dimana sinyal mencapai batas maksimumnya sehingga pada bitrate diatas 1500 Kbps kenaikan performansi tidak begitu signifikan terjadi. Persentase kenaikan nilai ODG untuk seluruh sampel audio yang diuji mencapai 9,6927\%. Secara umum komposisi downmixing berpengaruh terhadap kualitas audio yang dihasilkan. Dapat terlihat dari nilai ODG percobaan audio applause22ch, lebih baik dengan rata-rata berada di nilai $-0,3411 \mathrm{~dB}$, sedangkan bulg22ch, dan folk22ch rata-rata nilainya $0,5808 \mathrm{~dB}$ dan $-0,5793 \mathrm{~dB}$.

\section{Ucapan Terima Kasih}

Ucapan terima kasih kepada Lembaga Penelitian Pengabdian Masyarakat (LPPM) Universitas Andalas dan Fakultas Teknik Universitas Andalas atas pendanaan Penelitian ini.

\section{Daftar Rujukan}

[1] T. Hatada, H. Sakata, and H. Kusaka, "Psychophysical Analysis of the 'Sensation of Reality' Induced by a Visual Wide-Field Display," SMPTE J., vol. 89, no. 8, pp. 560-569, 1980, doi: 10.5594/J01582.

[2] M. Bosi and R. E. Goldberg, "Introduction to Digital Audio Coding and Standards," in Kluwer Academic Publishers, USA: Kluwer Academic Publishers, 2002.

[3] Y. Shishikui, K. Iguchi, S. Sakaida, K. Kazui, and A Nakagawa, "High-Performance Video Codec for Super HiVision," in Proceedings of the IEEE, 2013, vol. 101, no. 1, pp. 130-139, doi: 10.1109/JPROC.2012.2205656.

[4] T. Ito, "Future television - Super Hi-Vision and beyond," in 2010 IEEE Asian Solid-State Circuits Conference, 2010, pp. 14, doi: 10.1109/ASSCC.2010.5716546.

[5] E. Nakasu, "Super Hi-Vision on the Horizon: A Future TV System That Conveys an Enhanced Sense of Reality and Presence," IEEE Consum. Electron. Mag., vol. 1, no. 2, pp. 36 42, 2012, doi: 10.1109/MCE.2011.2179821.

[6] S. Kim, Y. W. Lee, and V. Pulkki, "New 10.2-Channel Vertical Surround System (10.2-VSS); Comparison Study of Perceived Audio Quality in Various Multichannel Sound Systems with Height Loudspeakers," 2010.

[7] K. Hamasaki, T. Nishiguchi, R. Okumura, Y. Nakayama, and A. Ando, "A 22.2 multichannel sound system for ultrahighdefinition TV (UHDTV)," SMPTE Motion Imaging J., vol. 117, no. 3, pp. 40-49, 2008, doi: 10.5594/J15119.
[8] K. Hamasaki, Y. Nakayama, T. Nishiguchi, and R. Okumura, "Wide Listening Area with Exceptional Spatial Sound Quality of a 22.2 Multichannel Sound System," J. Audio Eng. Soc., 2007.

9] T. Sugimoto, Y. Nakayama, and S. Oode, "Bit rate of 22.2 multichannel sound signal meeting broadcast quality," in The 137th Convention of the Audio Engineering Society, 2014, pp. 537-546.

[10] Y. Nakayama et al., "Live Production and Transmission of Large-Scale Musical TV Program using 22.2 Multichannel Sound with Ultra High Definition Video," Int. Broadcast. Conv. Conf., 2007, [Online]. Available: http://www.ibcshow.com/IBC2007/.

[11] K. Matsui et al., "Binaural Reproduction of 22.2 Multichannel Sound with Flat Panel Display-Integrated Loudspeaker Frame for Home Use," J. Inst. Image Inf. Telev. Eng., vol. 68, pp. J447-J456, 2014, doi: 10.3169/itej.68.J447.

[12] I. Elfitri and A. Luthfi, "Reviews on Technology and Standard of Spatial Audio Coding," J. Nas. Tek. Elektro, vol. 6, no. 1, p. 44, 2017, doi: 10.25077/jnte.v6n1.372.2017.

[13] M. Sobirin and I. Elfitri, "Perancangan dan Analisis Kinerja Pengkodean Audio Multichannel Dengan Metode Closed Loop," J. Nas. Tek. Elektro, vol. 3, no. 2, p. 157, 2014, doi: 10.25077/jnte.v3n2.80.2014

[14] I. Elfitri, R. Kurnia, and Fitrilina, "Investigation on objective performance of closed-loop spatial audio coding," in 2014 6th International Conference on Information Technology and Electrical Engineering (ICITEE), 2014, pp. 1-6, doi: 10.1109/ICITEED.2014.7007926.

[15] A. Luthfi, A. K. Permana, O. Saputra, and I. Elfitri, "Experimental Study of MPEG Surround for Stereo Audio Transmission," in 2018 International Conference on Information Technology Systems and Innovation (ICITSI), 2018, pp. 531-535, doi: 10.1109/ICITSI.2018.8695996.

[16] A. Luthfi, F. Mustaqim, and I. Elfitri, "Studi dan Analisis Kinerja Mpeg Surround pada Bitrate 256 - $400 \mathrm{Kbps,"} \mathrm{J.} \mathrm{Nas.}$ Tek. Elektro, vol. 5, no. 3, p. 325, 2016, doi: 10.25077/jnte.v5n3.302.2016.

[17] I. Elfitri, A. Luthfi, and Fitrilina, "R-TTT module with modified residual signal for improving multichannel audio signal accuracy," in 2015 International Conference on Automation, Cognitive Science, Optics, Micro Electro-Mechanical System, and Information Technology (ICACOMIT), 2015, pp. 207-211, doi: 10.1109/ICACOMIT.2015.7440207.

[18] K. Hamasaki, K. Hiyama, and R. Okumura, "The 22.2 Multichannel Sound System and Its Application," J. Audio Eng. Soc., 2005

[19] I. Elfitri, H. D. Laksono, and A. K. Permana, "Balanced-delay filterbank for Closed-Loop Spatial Audio Coding," in 2015 International Seminar on Intelligent Technology and Its Applications (ISITIA), 2015, pp. 403-408, doi: 10.1109/ISITIA.2015.7220014.

[20] I. Elfitri, X. Shi, and A. Kondoz, "Analysis by synthesis spatial audio coding," Signal Process. IET, vol. 8, no. 1, pp. 30-38, 2014, doi: 10.1049/iet-spr.2013.0015.

[21] J. Breebaart, G. Hotho, J. Koppens, E. Schuijers, W. Oomen, and S. Par, "Background, Concept, and Architecture for the Recent MPEG Surround Standard on Multichannel Audio Compression," J. Audio Eng. Soc, vol. 55, no. 5, pp. 331-351, 2007.

DOI: https://doi.org/10.29207/resti.v5i5.3372

Creative Commons Attribution 4.0 International License (CC BY 4.0) 
Vitral JR, Ahmad Ridwan, Habib Satria, Ikhwana Elfitri

Jurnal RESTI (Rekayasa Sistem dan Teknologi Informasi) Vol. 5 No. 5 (2021) 843 - 852

[22] L. Novamizanti, G. Budiman, and B. Wibowo, "Optimasi [23] Sistem Penyembunyian Data pada Audio menggunakan Subband Stasioner dan Manipulasi Rata-rata Statistik," ELKOMIKA J. Tek. Energi Elektr. Tek. Telekomun. Tek. Elektron., vol. 6, no. 2, p. 165, 2018, doi: 10.26760/elkomika.v6i2.165.

23] C. Faller and F. Baumgarte, "Efficient representation of spatial audio using perceptual parametrization," in Proceedings of the 2001 IEEE Workshop on the Applications of Signal Processing to Audio and Acoustics (Cat. No.01TH8575), 2001, pp. 199202, doi:10.1109/ASPAA.2001.969577.

DOI: https://doi.org/10.29207/resti.v5i5.3372

Creative Commons Attribution 4.0 International License (CC BY 4.0) 